Универзитет у Приштини са привременим седиштем у Косовској Митровици, Филозофрски фракултет - Катедра за енглески језик и књижевност, Косовска Митровица

DOI 10.5937/kultura1650157J 821.111(73).09-31 Дик Ф. К. 791.026:821.111(73)-31

оригиналан научни рад

\title{
ФИЛИПК. ДИКУ AMA3OHOBOM ABOPLLY
}

\begin{abstract}
Сажетак: Серија Човек у високом двориу приметно се разликује од романа Филипа К. Дика по којем је снимљена, али верност адаптаиије свакако је изгубила доминантно место у теорији и критици. Уколико се релевантним критеријумом за вредновағе адаптације сматра успешност у превођењу и преношењу идеја књижевног дела, ова серија то није успела да уради. Она уводи и наглашава елементе који производе, интензивирају и умножавају Диково лажно лажно уместо оних који доприносе спознаји унутрашње истине. Усредсређивањем на повриинске последиче губитка рата, а не на Америку као ауторитарну творевину у којој се, због бесомучне репликаиије, не само предметима, него и стварностима вите не може поуздано потврдити аутентичност, она не успева да укаже на кључне друштвене, економске и политичке проблеме и дилеме тадашњег и садашњег доба, као што то Дикове јединствене фикционалне стварности чине. Идеја лажног лажног, нажалост, гледаоиима је најуспешније пренета трансформаиијом романа у производ са потенцијалом за бесомучно репликовање $u$ комериијалну експлоатаиију.
\end{abstract}

Кључне речи: адаптација, научна фантастика, фикционалне стварности, аутентично, лажно

Научнофантастичне књижевне визије развоја људског друштва понекад застрашујуће успешном способношћу екстраполације и предикције указују на неке од најзначајнијих проблема и дилема с којима се суочава савремени човек. Ово готово дијагностичко својство научнофантастичне књижевности, укорењено у спекулативним премисама, научнотехнолошким иновацијама, слободи маште и спремности да искораком у непознато гради мост између фантастичног и стварног, при чему тренутно у виду имамо дела настала у 
периоду од шездесетих до осамдесетих година прошлог века, заслужно је што су бројни елементи фикционалних будућности препознатљиви и у савременој стварности. Ипак, читање данас, из перспективе времена које је у бројним научнофантастичним делима описано као будуће, показује да нису сва дела, нити сви писци, једнако успешни у предвиђању будућности, због чега није лако одолети констатацији да је време сустигло писце, чак престигло домашај њиховог књижевног увида у будућност, с којим се жанр пречесто повезује. Међутим, то би било клишетирање бројних научнофантастичних дела и њихово смештање у домен окултног, чему се неретко и сами писци опиру.

Филип К. Дик, један од најзначајнијих америчких писаца научне фантастике, у својим делима заснованим на идеји плурализма стварности, није успешно предвидео конкретне догађаје и технологију будућности, али јесте дијагностиковао дилеме и развој проблема с којима се човек суочава данас - а то су опасности глобализације, комодификације и замагљивања некада јасних граница између природног и произведеног, чија је последица немогућност јасног разграничавања аутентичног и копије, на нивоу предмета, појава, људског бића, чак и стварности. Филип К. Дик је сматрао да научна фантастика нема улогу да предвиђа будућност; „научнофантастичне књиге и приче”, , како је изјавио у интервјуу Грегу Рикману (Gregg Rickman), „не треба оцењивати на основу тога да ли су се описани догађаји заиста догодили или не, јер би у том случају постојала једна научнофантастична књига. Само једна права."2 Уколико се, уз наведену Дикову тврдњу и особености његове прозе, у обзир узму и научне теорије о постојању мултиверзума, јасно је да је погрешно и неосновано инсистирање на предиктивним својствима жанра, као и свођење на једно, једино и аутентично, било да су у питању приче, књиге, предмети, људи и/или стварности, јер уколико нема једне праве стварности, онда нема ни једне будућности, па самим тиме ни само једне, праве научнофантастичне књиге. Ово значи да су, потенцијално, све оне праве. Или пак да ниједна није права. Бројна дела, читана у време које описују као будуће, потврђују да се у предиктивна својства научне фантастике не треба поуздати. Могуће је навести и бројне примере искустава који показују да је стварност препуна илузија, обмана и погрешне, или бар другачије, перцепције, што је чини

1 Сви наводи из непреведене литературе дати су у преводу аутора овог текста.

2 Цитирано у: Vest, J. Р. (2007) Future Imperfect: Philip K. Dick at the Movies, Westport CT: Praeger Pubishers, p. 178. 
сличном научнофантастичној књижевности. У овом вртлогу тврдњи, које се међусобно негирају и потврђују, налази се и стваралаштво Филипа К. Дика.

Да у овом вртлогу можда има и истине показују преклапања између фикционалних стварности и такозваног стварног света, подручја подједнако у домену фантастике и стварности, која књижевне визије будућности трансформишу у огледала, каткад искривљена, у којима се назиру одрази садашњости. Актуелност таквих одраза потврђује раст популарности научнофантастичне прозе, чему доприносе упечатљивост књижевних визија и лакоћа саживљавања с њима, упркос бројним одступањима од познате стварности, а нарочито све бројнији филмови и серије снимљени по научнофантастичним делима, о чијој популарности сведочи број научнофантастичних наслова на листама најгледанијих филмова и њихов комерцијални успех, што заузврат доводи до пораста броја продатих примерака књига по којима су адаптације снимљене.

Између прозе Филипа К. Дика и филмске индустрије такође је развијен овакав узајамно користан и комерцијално успешан однос. Филм Истребљивач (Blade Runner, 1982), рађен по роману Сањају ли андроиди електричне овие? (Do Androids Dream of Electric Sheep?, 1968), прва је филмска адаптација једног његовог дела. Након овог филма, како Bест (Vest) примећује, Диково целокупно стваралаштво - 125 прича, 46 романа, и више збирки кореспонденције, добијају нова издања (или се по први пут појављују у штампи). ${ }^{3}$ У предговору Дикове биографије, Лоренс Сатин (Lawrence Sutin) раст популарности Дикове прозе у америчкој култури радије приписује његовом списатељском таленту него филмским адаптацијама, од којих су бројније само оне рађене по делима Стивена Кинга. ${ }^{4}$ Данас, за разлику од 2005. године, када је објављено издање ове биографије с поменутим предговором, иако је снимљен значајан број филмова по Диковим романима и причама, тешко је поредити било ког писца са комерцијалношћу и бројем адаптација Кингових дела.

Сатин филмске адаптације Дикових дела, изузев Истребљивача, сматра ужасним - Шварценегер у Тоталном опозиву (Total Recall, 1990) није ни покушао да дочара протагонисту романа, док су остале, од Уљеза (Impostor, 2001) до Исплаme (Paycheck, 2003) успеле у ономе што је, када је Дик у

3 Ibid, p. 179.

4 Sutin. L. (2005) Divine Invasions: A Life of Philip K. Dick, New York: Carol \& Graf-Avalon), p. XI. 
питању, ретко случај - да се публика уз њих досађује. ${ }^{5}$ За разлику од Сатина, Џејсон П. Вест, уз похвале, утицај идеја и мотива из Дикових дела примећује и у серијама и филмовима који нису њихова директна адаптација, наводећи пар десетина примера, међу којима су трилогија Матрикс (The Matrix, 1999-2003), Отвори очи (Abre los ojos, 1997) и његов амерички римејк Небо боје ваниле (Vanilla Sky, 2001), Дванаест мајмуна (Twelve Monkeys, 1995), Шесто чуло (The Sixth Sense, 1999), Свемирска крстарища Галактика (Battlestar Galactica, 2004-2009). Ове и бројне друге познате наслове, како Вест примећује, с Диковим делима повезује мотив краха стварности или немогућност разликовања једне стварности од друге, или више њих. ${ }^{6}$

Списку наслова повезаних наведеним мотивом див интернет продаје, Амазон, додао је још једну директну адаптацију, серију Човек у високом двориу (The Man in the High Castle, 2015) снимљену по истоименом роману Филипа К. Дика (1963). Роман и серија описују алтерантивну стварност у којој су се догађаји одиграли другачије него у познатој историји - након победе сила Осовине у Другом светском рату Сједињене Америчке Државе постају окупирана територија. Јапан контролише запад, такозване Пацифичке Америчке Државе (ПАД), Немачка је окупирала источни део земље, а између њих се налази релативно мала неутрална територија Држава Стеновитих Планина. У овом свету, ликови су суочени са могућношћу да, осим стварности у којој живе, постоје и друге, не мање стварне стварности.

За разлику од агресивних и технолошки надмоћних Немаца, чије освајачке, идеолошке и економске амбиције подривају крхки савез две победничке силе, претећи да ескалирају у отворен војни сукоб, одмеренији и саосећајнији Јапанци показују склоност да упознају културу покорене нације, да је подражавају, чак да се поистовете с америчким начином живота. Њихова жеља да поседују предмете из америчке предратне прошлости добија размере опсесије због које су имућни појединци спремни да потроше значајне своте новца на вредне антиквитете, као што су примерци оружја из Америчког грађанског рата, али и на готово бизарне колекционарске предмете из америчке популарне културе и потрошачке историје, као што су сатови с ликом Микија Мауса, затварачи за боце, карте и сличице из паковања жвакаћих гума. Будући да је потражња већа од понуде, на тржишту антиквитета и уметнина, уз оригиналне предмете, продају 
се и реплике, брижљиво обрађени фалсификати тешко разазнатљиви од оригинала. Сједињене Државе, у објективној стварности војно и технолошки супериорна светска сила, у фикционалној стварности романа сведене су на колонију за производњу фалсификованих сведочанстава сопствене прошлости.

Френк Фринк, прикривени Јевреј из Пацифичких Америчких Држава, ради за корпорацију Вајндам-Метсон у чијем су производном програму, осим легалних производа, и фалсификати пласирани на тржишту америчких предратних уметнина и предмета. Осим Френка, у серији се појављују и други ликови из романа: Џо Ћинадела, презимена промењеног у Блејк, који ради за Немце и има мисију да убије Хоторна Абендсена, писца забрањене књиге; затим јапанофил Роберт Чилдан, власник антикварнице с америчким уметнинама; Рудоф Вегенер, Немац који долази у ПАД да упозори Јапанце на претњу од немачког напада; Нобусуке Тагоми, високопозиционирани службеник јапанске владе у трговинској мисији, као и Џулијана Фринк, ${ }^{7}$ која је у књизи бивша супруга Френка Фринка и живи далеко од њега, у неутралној зони, док у серији њих двоје живе заједно као невенчан пар. Ово је само једна од бројних разлика између романа и серије.

Љубавна авантура између Џулијане и Џоа, у књизи сурово окончана његовим пререзаним вратом након што она открије његову намеру да убије Абендсена, у серији је развијена у значајан део заплета и Џулијана је та која на крају последње епизоде прве сезоне Џоу спашава живот. Роберту Чилдану је у серији придат много мањи значај него у роману, у којем су судбине свих ликова и последице њихових поступака много директније повезане и испреплетене. Френк у серији има сестру и сестриће, након чијег погубљења преузима активнију улогу у отпору окупатору и планира убиство јапанског престолонаследника. Џулијана, такође, има сестру, која је непосредно пре смрти уплиће у опасну мисију ношења спорног видео-записа на неутралну територију. Ед Макарти, с којим Френк у роману прави оригинални накит, у серији доживљава другачију судбину, док Рудолф Вегенер у суштини има исту улогу, мада нема исти војни чин.

Није неоправдано у адаптацију уводити елементе који је чине другачијом од дела по којем је снимљена. Роберт Стем (Robert Stam) у есеју „Мимо верности” примећује да ликови могу претрпети суптилне промене у филмским адаптацијама, у којима, иако оне имају тенденцију да жртвују „вишак”

7 У преводу романа њено име је транскрибовано у Јулијана. 
ликова из романа, постоје случајеви када се дешава супротно - додавање нових ликова. ${ }^{8}$ Један од примера је и серија Човек у високом двориу, с бројним ликовима којих у Диковом роману нема. Међу њима, најзначајнију улогу има Џон Смит, виши вођа групе (Obergruppenführer), Џоов налогодавац и вођа акције неутралисања покрета отпора у Њујорку. Лемјуел Вашингтон, Карен, Рандал и други чланови покрета отпора, па и сам покрет, такође постоје само у серији. У роману нема ни Човека с оригамијем, нацистичког агента послатог на неутралну територију да елиминише чланове отпора, као ни Шерифа, ловца на уцењене главе, који носи колекцију флашица са прстима својих жртава. Новоуведени ликови, те бројне друге измене, серију чине упадљиво другачијом од романа, због чега се за њу не може рећи да је његова верна адаптација. Међутим, верност адаптације одавно је изгубила доминантно место у теорији и критици, где је њен значај оспорен другим питањима и критеријумима.

Проблематична питања и критеријуме Томас Лич (Thomas Leitch) сумира у есеју „Дванаест заблуда у савременој теорији адаптације", 9 неке од којих су: да су разлике између књижевног и кинематографског текста укорењене у суштинским особинама медија, да су књижевни текстови вербални а филмски визуални, да су романи бољи од филмова, да романи стварају комплексније ликове од филмова јер имају директнији и потпунији приступ стању ума ликова, да су изворни текстови оригиналнији од адаптација, као и да је верност најадекватнији критеријум за анализу адаптације.

На неоправданост верности као вредносног критеријума Роберт Стем указује објашњењем да, када кажемо да адаптација није верна оригиналу, то указује на разочарање због њеног неуспеха да пренесе суштину текста, тематске и естетске особености књижевног извора. ${ }^{10}$ Стем овим сугерише да је верност искључиво ствар личног и субјективног, емотивног става према књижевном делу и његовој адаптацији заснованог на нашем осећају да су неке адаптације боље од других, док неке не успевају да остваре оно што у романима највише ценимо. Ипак, како он запажа, као што сваки текст може бити схваћен на безброј начина, сваки роман може да

8 Stam, R. Beyond Fidelity: The Dialogics of Adaptation, in: Film and Literature: An Introduction and Reader, ed. Corrigan, T. (2012), New York: Routledge, p. 84.

9 Leitch, T. Twelve Fallacies in Contemporary Adaptation Theory in: Film and Literature: An Introduction and Reader, ed. Corrigan, T. (2012), New York: Routledge, pp. 104-122.

10 Stam, R. op. cit., p. 75. 
створи безброј адаптација. ${ }^{11}$ Стем наводи више разлога због којих сматра да је верност неадекватан критеријум за вредновање адаптације. На пример, док читамо књижевно дело, стварамо замишљени мизансцен романа у уму, зато што га читамо кроз призму сопствених подсвесних жеља, надања, утопија. Још један пример је пишчев опис особе као лепе - читаоци ту особу замишљају, па речи у роману имају виртуално значење јер, без обзира на то колико је опис детаљан, читаоци део увек допуњавају у својим умовима, док је за улогу у филму неопходно одабрати глумца, чија лепота можда не испуњава свачија очекивања. Оно што је уопштено у тексту мора да буде конкретно на филму, те сам процес снимања аутоматски прави разлику. Сходно томе, верност не треба да буде искључиви методолошки принцип, јер је могуће закључити да је адаптација аутоматски другачија због промене медија, па је питање да ли је она уопште могућа. ${ }^{12}$ Коначно, Стем поставља питање - верност чему? Да ли треба бити веран намерама аутора? Које су намере? Како их утврдити? Којем елементу ауторства треба бити веран? Биографском аутору? Наратору? Стилу? Тачки гледишта? ${ }^{13}$

Имајући у виду наведено, поставља се питање сврсисходности анализе адаптације поређењем с делом на основу којег је настала. Ипак, као што то наведени теоретичари указују, а у наредном случају и сам аутор дела по којем је снимљен филм, одступања од оригинала, као што су изостављање делова и убацивање нових ликова и елемената радње, нису увек неоправдана, нити нужно увек изазивају негативне критике. Како Дик наводи, Ридли Скот (Ridley Scott) му је признао да му је роман Сањају ли андроиди електричне овие? био тежак за читање, док њему самом читање сценарија Истребљивача није представљало никакав проблем. Такође, мада сценарио није имао много везе с књигом, био му је сјајан, чак у неку руку бољи од ње - сматрао је да су сукоб андроида с људима, њихово међусобно убијање и општа збрка веома узбудљиви за гледање.

„Ипак, не бисте желели да мој роман видите на екрану јер је пун људи који разговарају, као и због личних проблема протагонисте. Такви елементи се не преводе на екран. А зашто их и преводити, када је роман прича у речима, док

11 Ibid, p. 80 .

12 Ibid, p. 75

13 Ibid, p. 77 


\section{МЛАДЕН ЈАКОВЉЕВИЋ}

је филм догађај у покрету? Не зову их узалуд покретним сликама. Ја немам примедби." ${ }^{14}$

Као писац, желео је да види неке од својих идеја на филму, а не само специјалне ефекте, којима је приписао фасцинантан успех научнофантастичних филмова. Његово искуство и пример Истребљивача, у којем су идеје из романа успешно пренете на екран, потврђују да адаптације имају смисла и да се, упркос разликама, два дела могу поредити, уколико се имају у виду не само особености оба медија, него и специфичности трансформације садржаја из једног медија у други. Осим што, такође, не истиче верност као значајан критеријум, Дик користи реч „превод”, коју и Стем предлаже уместо верности јер указује на принципијелна настојања карактеристична за интерсемиотичку транспозицију, укључујући неизбежне предности и мане сваког превођења. ${ }^{15}$

Андре Базен (André Bazin), француски филмски критичар и теоретичар, сматра да је роман јединствена синтеза на чију молекуларну равнотежу промена форме аутоматски утиче. Форма је, како Базен наводи, знак, видљива манифестација стила нераздвојива од наративног садржаја, па је верност форми, књижевној или било којој другој, илузорна. Базен је против верности као примарног критеријума за филмску адаптацију и сматра да процес адаптације треба да оствари кинематографски еквивалентна значења форми, зато што ликови, приче и значења из романа постоје мимо површинског стила, те другачијим формалним еквивалентима они могу бити једнако представљени у другачијем медију. ${ }^{16}$

У серији Човек у високом двориу дело Хоторна Абендсена је пример таквог другачијег формалног еквивалента. У Диковом делу Абендсен је написао Скакаваи притиска, роман забрањен на територијама под немачком окупацијом због описа контроверзног алтернативног света у којем је, у одређеном тренутку, дошло до прекида континуитета с познатом историјом. У Абендсеновом роману Америка није поражена, силе Осовине су изгубиле рат и немачка суровост је заустављена. Пратећи аналогију превода текста Диковог романа у серију, преводом Абендсеновог текста у форму видео-записа, метатекст Скакавиа, роман унутар романа, постаје метафилм, видео-запис унутар видео-записа.

14 Dick, P. K. Universe Makers... and Breakers, in: The Shifting Realities of Philip K. Dick: Selected Literary and Philosophical Writings, ed. Sutin, L. (1995), New York: Vintage/Random House, pp. 104-105.

15 Stam, R. op. cit., p. 80.

16 Bazin, A. Adaptation, or the Cinema Digest, in: Film and Literature: An Introduction and Reader, ed. Corrigan, T. (2012), New York: Routledge, p. 58. 
Превођењем је, у овом случају, очуван еквивалентан однос између фикционалне стварности текста/серије и у њу уметнуте алтернативне стварности метатекста/метафилма, као и еквивалентно искуство перцепције, то јест медија путем којег читаоци/гледаоци перципирају фикционалну стварност Човека у високом двориу, а ликови алтернативну стварност унутар ње.

Делови приче могу бити изостављени из адаптације због неопходног кондензовања романа у филмски запис. Како Вест примећује, Ричард Линклејтер (Richard Linklater), Ридли Скот и Жером Боаван (Jérôme Boivin) током рада на Тамном скенирању (A Scanner Darkly, 2006), Истребљивачу и Баржсу (Barjo, 1992) морали су да сведу романе од преко 200 страна на филмску дужину. У Истребљивачу то је постигнуто избацивањем свих експлицитних референци и делова који се односе на мерцеризам. ${ }^{17}$ Сличном захвату прибегавају и аутори серије Човек у високом двориу, посвећујући Кюизи промена свега неколико успутних референци и кадрова.

Ји Ђинг - Кьига промена, коју у алтернативну Америку доносе јапански бизнисмени и бирократе, има вишеструку улогу. Она указује на постојање значајних сличности између Јапанаца и становника америчких држава под њиховом окупацијом. Као што Јапанци купују и сакупљају предмете из америчке предратне историје и културе, наговештавајући својеврстан покушај идентификације с њом, Американци опсесивно консултују ову књигу, која брзо постаје неизбежно саветодавно средство за доношење свих важних одлука. На значај Кюиге промена указују мистични хексаграми, које читаоци добијају као одговоре на своја питања. Господин Тагоми консултује Кюигу из страха да је својим поступцима одлутао од Таоа и као одговор добија хексаграм 47, чије значење је „УГњетавање, исцрпљење”. ${ }^{18},{ }^{19}$ Видевши да се јапанском брачном пару Касура допао поклон који им је донео, Роберт Чилдан његову улогу и реакцију прималаца види као „приношење жртве” и ,помазање”, ${ }^{20}$ то јест доводи га у везу са истим хексаграмом који добија и Френк Фринк

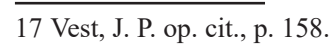

18 Dik, F. K. (2008) Čovek u visokom dvorcu (prev. Rajković, M.), Beograd: Alnari, str. 132.

19 Осим превода назива хексаграма у роману, доступни су и преводи: „Тешкоћа” у издању Albahari, D. ur. (2005) Ji đing, deset krila: knjiga promene, Sremska Mitrovica: Tabernakl; „Исцрпљивање” у Huang, A. (2009) Sveobuhvatni Ji Đing / definitivni prevod taoističkog majstora Alfreda Huanga, Beograd: Babun.

20 Дик, Ф. К. нав. дело, стр. 138. 
када пита да ли ће добити новац од бившег послодавца, а то je број 47, у чијем опису је наведено да „[ч]овеку помаже да приноси жртве и даје помазања". ${ }^{21}$

Къига промена је неопходна за тумачење једне од најзначајнијих, могућих, али не и недвосмислених, потврда истинитости света описаног у Абендсеновом роману - доживљаја господина Тагомија када га брош, који је направио Френк, преноси у другу стварност. Вредност брошу не даје изглед, нити материјал од којег је направљен, него ву који он садржи. $B y$, „мудрост” или „разумевање”, 22 обично се, како господин Касура у роману објашњава, „налази на најнеугледнијим местима."

„Човек доживљава свест о вуу у таквим отпацима као што су стари штап или зарђала конзерва од пива крај пута. То је религиозни доживљај. Овде је један мајстор ставио ву у предмет, уместо да само посведочи ву који се ту налази."23

Господин Тагоми истину за којом трага не може да спозна чулима: видом, слухом, мирисом и додиром. Аутопут Ембаркадеро и обличја њему чудних аутомобила у алтернативном, прљавом, бучном Сан Франциску у којем он, као Јапанац, не ужива очекивану пажњу и поштовање, говоре му да је изван познате стварности, изван „свог света, свог простора и времена". ${ }^{24}$ У лажној стварности, потенцијално препуној фалсификата и обмана, само предмет с истинском енергијом вуа може да открије истину господину Тагомију. Етерична снага аутентичних предмета и рукотворина разоткрива плурализам стварности, због чега сви ликови инстинктивно теже да их поседују. Роберта Чилдана ужасава могућност да су, уз револвер за који добија потврду да је фалсификат, још неки предмети у његовој понуди лажни. Господин Тагоми, након што убије Немце који желе да се пробију до његове канцеларије, жели револвер да замени за предмет који није лажан, за „неку ствар која има потврђени историјат”. ${ }^{25}$ Чилдан и Тагоми, попут Френка, који почиње да прави аутентичне предмете, или Џулијане, која креће ка Абендсену да сазна истину о његовој књизи, па и самог Абендсена, који је написао Скакавиа - потврдом о аутентичности предмета уједно желе да потврде, или оспоре, аутентичност стварности и себе у њој.

\footnotetext{
21 Исто, стр. 132.

22 Исто, стр. 226.

23 Исто, стр. 227.

24 Исто, стр. 229.

25 Исто, стр. 289.
} 
Попут предмета који садржи ву, хексаграм 61, „Унутрашња истина", ${ }^{26},{ }^{27}$ нуди верзију могуће истине о устројству стварности. Након сазнања да је Абендсен књигу писао користећи Кюигу промена, Џулијана Књигу пита зашто је написала Скакавияа и као одговор добија хексаграм 61, као и господин Тагоми, који Къигу консултује након убиства агената немачке безбедносне службе.

Спознаја унутрашње истине одраз је Дикове теорије да сваки појединац можда доживљава засебну, другачију, сопствену стварност.

„Можда свако људско биће живи у јединственом свету, приватном свету, свету који се разликује од оног који настањују и доживљавају друга људска бића. А то ме је навело да се запитам. Уколико се стварност разликује од особе до особе, можемо ли онда да говоримо о јединственој стварности, или би пре требало да говоримо о више стварности? Уколико постоји више стварности, да ли су неке истинитије (стварније) од других? Шта је са светом шизофреничара? Можда је једнако стваран као и наш свет." 28

Попут Абендсена, Дик је Човека у високом двориу писао консултујући Книгу промена. ${ }^{29}$ Неопходно је имати у виду да он Къигу није користио као пророчиште, него да би добио потврду својих теорија о времену, шизофренији и перцепцији стварности, које се значајно разликују од општеприхваћених теорија (у стварности у којој је живео). У есеју „Шизофренија и Кюига промена" Дик објашњава да је у Кюизи уочио принцип упоредив са његовим схватањем перцепције шизофреничне особе, која стварност доживљава као да се све дешава сада, без осећаја линеарног тока времена. Овакву перцепцију он је поредио с доживљајем гледања филма за разлику од већине људи, који стварност доживљавају линеарно, кадар по кадар, шизофреничне особе све кадрове виде истовремено. Ово стање без поделе на прошлост, садашњост и будућност, које он назива синхроницитет, у Књизи промена омогућава увид у ванвременске силе, што значи да она не прориче, него омогућава формирање претпоставки

26 Исто, стр. 309.

27 „Увид (унутрашња истина)” у издању Албахари Д. нав. дело; „Унутрашња Искреност” у Хуанг, А. нав. дело.

28 Dick, P. K. How to Build a Universe That Doesn't Fall Apart Two Days Later, in: The Shifting Realities of Philip K. Dick: Selected Literary and Philosophical Writings, ed. Sutin, L. (1995), New York: Vintage/Random House, p. 261.

29 Dick, P. K. Schizophrenia \& The Book of Changes, in: The Shifting Realities of Philip K. Dick: Selected Literary and Philosophical Writings, ed. Sutin, L. (1995), New York: Vintage/Random House, pp. 181-182. 
о могућностима које питалац из своје перспективе линеарног поимања времена доживљава као будућност. Због синхроницитета, како Дик објашњава у есеју, Кьигу промена редовно могу да користе само шизофреничне особе. Делимично шизофреничне особе треба да користе књигу само у одређеним ситуацијама, за питања од изузетног значаја, док остали, који нису шизофренични, одговоре у њој треба да траже што је ређе могуће. Имајући ово у виду, сви ликови у роману су потенцијално шизофренични јер Кюигу редовно користе, што значи да су њихови светови можда једнако стварни као и наш(и).

За разлику од Истребљивача, у којем се изостављање мерцеризма није одразило на идеју губитка људскости и индивидуалности због бесомучне репликације и комодификације свега, укључујући предмете, људе, па и сам доживљај стварности, у серији Човек у високом двориу маргинализовање Кьиге промена без адекватног еквивалента за преношење, то јест превођење примарних идеја из романа, ускраћује најзначајнији механизам спознаје унутрашње истине. Кюига није успутна појава, није културолошки фетиш, није декор за сликовитије представљање необичности културе другог, неамеричког народа, није унутрашњи точкић механизма чију улогу простом заменом може да преузме други точкић. Она је спољашњи оквир унутар којег се све догађа, садржи одразе свих алтернатива стварности и указује на постојање мноштва интертекстуалних универзума, у којем један текст, самим тим и један свет, није мање или више значајан од другог.

Дик је покушавао да пронађе одговоре на два суштинска питања: „Шта је стварност? Шта чини аутентично људско биће?” За разлику од првог питања на које, како је то и сам признао, није успео да пронађе одговор, веровао је да је на друго питање могуће дати конкретне одговоре. ${ }^{30}$

„Бомбардовање псеудостварностима веома брзо почиње да ствара неаутентичне људе, лажне људе - лажне као и подаци који их притискају са свих страна. Моје две теме су у ствари једна тема; сједињују се у овој тачки. Лажне стварности створиће лажне људе. Или, лажни људи ће створити лажне стварности и онда их продати другим људима, чиме ће их на крају претворити у сопствене фалсификате. Тако завршимо с лажним људима, који измишљају лажне стварности и онда их продају другим лажним

30 Dick, P. K. How to Build a Universe That Doesn't Fall Apart Two Days Later, in: The Shifting Realities of Philip K. Dick: Selected Literary and Philosophical Writings, ed. Sutin, L. (1995), New York: Vintage/Random House, p. 278. 
људима. То је само једна веома велика верзија Дизниленда. Можете да имате Пиратску вожњу или Линколнов симулакрум или Луду вожњу господина Жапца - можете да имате све њих, али ниједна није истинита.

У писању сам се толико заинтересовао за лажно, да сам на крају дошао до концепта лажног лажног. На пример, у Дизниленду постоје лажне птице које раде на електромоторе, које гракћу и креште док пролазите поред њих. Замислите да се једне ноћи сви ми ушуњамо у парк с правим птицама и њима заменимо ове вештачке. Замислите ужас који би осетили званичници Дизниленда када би открили окрутну превару. Праве птице!"31

У роману, улогу правих птица у лажној стварности имају Кьига промена, Абендсенов роман и Френков брош.

„Дикова проза наговештава одсуство праве индивидуалности у постиндустријском и постхуманистичком друштву, чију стварност чине реплике без оригинала. У таквој симулацији стварности јављају се пукотине и нелогичности, ситне грешке, које показују да с таквим системима нешто суштински није у реду.”32

Осим што је дискутабилно колико је индијанска традиција аутентично америчка у контексту Америке какву данас знамо, фалсификован комад индијанског накита у серији, као еквивалент брошу из романа, иако је он Френкова рукотворина и садржи ву, покушај је изградње везе с аутентичном стварношћу предметом који није ,аутентично нова ствар на лицу земљином", 33 због чега је он попут лажне птице у забавном парку лажне стварности. Маргинализовање значаја Кьиге промена и аутентичних предмета, индикатора лажног у стварности, а тиме и лажности стварности, лишава серију, ликове у њој и гледаоце могућности да пронађу одговоре на питања за којима је Дик трагао.

Роман указује на радикално другачије поимање стварности и америчког начина живота у њој, што серија такође не успева да пренесе. За разлику од стварности романа, у којој је живот у источним државама попут боравка у војсци, „у радним логорима”, у „спаваонама што их имају на истоку”, где људи

\footnotetext{
31 Исто, стр. 263-264.
}

32 Jakovljević, M. (2015) Alternativne stvarnosti Filipa K. Dika, Kosovska Mitrovica/Beograd: Filozofski fakultet Kosovska Mitrovica/Makart doo., str. 183.

33 Dik, F. K. (2008) Čovek u visokom dvorcu (prev. Rajković, M.), Beograd: Alnari, str. 228. 
морају да „устају у пола седам ујутру, уз војну музику“, 34 у серији је он готово реплика познате америчке стварности са налепљеним свастикама. Џон Смит, нациста чије име је толико уобичајено да симболише одсуство индивидуалности, живи типично америчким породичним животом, у типичној америчкој кући, у типичном америчком предграђу.

Идеја постојања покрета отпора у серији потенцира очекивану, морално исправну, физичку реакцију покореног америчког становништва, јер је идеја да окупирана Америка не пружа отпор незамислива. Сличну улогу има и Френков недовршени покушај убиства јапанског престолонаследника, ехо атентата на Кенедија, чије је убиство синоним за ударац у срце система. Отворено конфронтирање зарад остварења циљева у нескладу је с поруком књиге. Промене у свести и перцепцији стварности нису неопходне због окупације државе и гашења демократије, него због унутрашње празнине, илузије да људи живе праве животе. Покрет отпора у књизи не постоји, као ни Френкова жеља да узме оружје и, резигниран због неправде, бола и ускраћене слободе да практикује своју веру, учини нешто да то промени, зато што такви поступци не омогућавају увид у унутрашњу истину, као што то чине поменути индикатори лажног у стварности и лажности стварности.

Пренаглашавање значаја улога које Џулијана, покрет отпора и Џон Смит имају на судбине других ликова и стварност уједно је њихова трансформација у лажно лажно. За разлику од филмских адаптација у којима постоји проблем кондензовања радње романа у сат и по или два сата трајања филма, десет епизода свакако омогућавају много више простора за појашњење улога које Кюига и аутентични предмети имају у процесу спознаје истине. Најава друге сезоне серије тај простор додатно увећава. Френк Спотниц (Frank Spotnitz), креатор и извршни продуцент серије, који Диков роман сматра научнофантастичним класиком, када је поново прочитао роман пре почетка рада на серији, увидео је, како каже, да нема „причу за телевизијску серију”, због чега je, трудећи се да сачува суштину књиге, причу проширио додавањем нових ликова, да „попуни свет на начин који је”, како се нада, „усклађен с оним што су биле намере и теме Филипа К. Дика." ${ }^{35}$

\section{4 Исто, стр. 91.}

35 Walker, D. The Man in The High Castle Writer Frank Spotnitz on Adapting Philip K. Dick for Amazon, 18 November 2015, 1 March 2016, http://www. phoenixnewtimes.com/arts/the-man-in-the-high-castle-writer-frank-spotnitz-on-adapting-philip-k-dick-for-amazon-7830812 
Наизглед недовршена прича и ликови у роману у функцији су идеје, чији значај је Дик нагласио у интервјуу Френку Бертрану.

„У научној фантастици је најзначајнија идеја динамичности. Догађаји се развијају из идеје која утиче на жива бића и њихово друштво. Идеја увек мора да буде нова. Ово је најзначајније питање научне фантастике, чак и лоше научне фантастике." ${ }^{\text {"3 }}$

Празнине у ликовима и њихова флуидност омогућавају уживљавање у њихове животе, дилеме, проблеме. Серија не оставља ту могућност као роман, јер фиксирање и „испуњавање" ликове трансформише у лажно лажно. У малом броју случајева, „испуњавање” заиста доприноси богатству приче и слике света, као што то чини сцена када господин Тагоми негује цвеће у својој башти или изглед његове канцеларије, о којој у роману знамо само да има клизна врата. Много чешће, она мења значајне конституенте Дикове фикционалне стварности у њихове неодговарајуће еквиваленте, који уз домишљене и додате делове приче, не само што његов свет не испуњавају, него, напротив, стварају његову испразну, дизнификовану верзију.

Фикционална стварност романа је визија застрашујуће, другачије Америке, ауторитарне и сурове псеудодржавне творевине, али последице изгубљеног Другог светског рата само су фасада те визије. Прави механизам, суштина њене трансформације, јесте производно-потрошачки систем фабриковања у којем индивидуалност нестаје, лажно замењује право, реплика аутентично, а контрола слободу. То је разлог зашто су у роману ликови малобројни, емоционално сакати, полупразни и недовршени, а њихови животи испразни док не открију унутрашњу истину. Серији недостаје овај подтекст. У њој има знатно више ликова, које су аутори настојали да трансформишу у „испуњене” појединце, који интензивно доживљавају емоционалне трауме, али они то раде са задршком, испрограмирано и контролисано. Френк и Џулијана смрт блиских особа испрва доживљавају бледо, реакција на трагедију готово да изостаје, да би емотивни излив уследио касније, када је то по сценарију прикладније, како се њихове реакције не би поклопиле с интензитетом и значајем других догађаја.

Упркос великом броју реконструисаних и додатих, домишљених детаља и ликова, серија је дводимензионални одраз

36 Bertrand, F. Philip K. Dick on Philosophy: A Brief Interview, in: The Shifting Realities of Philip K. Dick: Selected Literary and Philosophical Writings, ed. Sutin, L. (1995), New York: Vintage/Random House, p. 44. 
фикционалног света који не успева да пренесе идеју романа, нити да створи другу, истински нову идеју. Покрет отпора, атентат на престолонаследника, ловац на главе, Џон Смит и његова породична кућа у предграђу - ови елементи указују на константну потребу твораца серије да фикционалну стварност учине што сличнијом познатој Америци. Новоуведени елементи не само што не доприносе преношењу Дикових идеја и порука, него серију удаљавају од њих. За разлику од Кьиге промена, идеја покрета отпора је више одраз комодификоване стварности, визије патриотизма и борбе за правду и слободу. У серији, Америка је земља у којој се буди отпор и родољубље. У роману, то је земља коју Јапанци, упркос покушају да подражавају њену популарну културу и поседују артефакте из њене историје, суштински не разумеју, али је ипак цене много више него сами Американци. Игра картицама из паковања жвака симбол је њиховог односа према сопственој прошлости: за Јапанце то су вредни предмети, за Американце само забава.

Роман Човек у високом двориу треба да наведе читаоца да се запита да ли, осим његовог или њеног света, постоји још неки други, у којем су се ствари одиграле другачије. Попут Абендсенове књиге и Књиге промена, роман читаоцу указује на то да спознајом унутрашње истине може престати да буде појединац у мноштву лажних људи који измишљају лажне стварности. Серија уводи и наглашава елементе који производе, интензивирају и умножавају лажно лажно, уместо оних који доприносе спознаји унутрашње истине. Настојањем да дочара земљу након изгубљеног рата и усредсређивањем на његове површинске последице, а не на Америку као ауторитарну творевину у којој се, због бесомучне репликације, не само предметима, него и стварностима више не може поуздано потврдити аутентичност, сериja не успева да укаже на кључне друштвене, економске и политичке проблеме и дилеме тадашњег и садашњег доба, као што то јединствене филдиковске стварности чине. Уместо тога, серија гледаоцима нуди допадљиву телевизијску причу из америчке производно-потрошачке машинерије, прилагођену укусу већине, што је не чини нимало другачијом од конструката стварности на чију лажност Дикова дела упозоравају.

Дикова проза тражи од читаоца да сарађује и учествује у пројекту заједничке књижевне креације, што омогућава већу слободу интерпретације. ${ }^{37}$ Нажалост, када је серија Човек

37 Vest, J. P. (2009) The Postmodern Humanism of Philip K. Dick, Lanham, Toronto, Plymouth: The Scarecrow Press, Inc., p. 137. 


\section{МЛАДЕН ЈАКОВЉЕВИЋ}

y високом двориу у питању, слобода интерпретације у адаптацији раскида везе са јединственим, аутентичним светом Дикове фикционалне стварности.

Андре Базен је приметио да они који раде адаптације више брину о публици него о кинематографији као уметности. ${ }^{38}$ На бригу о публици указује одлука о снимању серије на основу реакција након пилот епизоде. ${ }^{39}$ Усредсређеност на жеље публике, уједно и конзумената у овом случају, наговештава да ликови неће потрагу окончати када спознају унутрашњу истину, него када та потрага више не буде комерцијално исплатива. Најава нових сезона серије и изјава Френка Спотница то потврђује - он није сигуран колико сезона ће серија трајати, али наглашава да ће у телевизијској причи у средишту пажње бити Џулијана, а не радња. Питања на која ће серија давати одговоре концентришу се око ње: „Зашто је она јунакиња? Који путем треба да иде и где му је крај? Јер тек када тај пут дође до краја и серији ће бити крај."

Уколико је успешност превођења идеја адекватан критеријум за вредновање адаптације књижевног дела, онда се може закључити да, маргинализовањем индикатора лажног и њиховом супституцијом лажним лажним: покретима отпора, ловцима на уцене са бизарним колекционарским навикама, ликовима са програмираним емоцијама и бројним одразима познате стварности, псеудостварност серије успева да пренесе само део идеје романа. Нажалост, она то чини искључиво сопственим потенцијалом за бесомучно репликовање и комерцијалну експлоатацију, што је чини још једном лажном стварношћу која ствара лажне људе, који ће „створити лажне стварности и онда их продати другим људима". ${ }^{41}$

38 Bazin, A. op. cit., p. 59.

39 Узимајући у обзир реакције на пилот епизоде и оцене публике Амазон одлучује који наслови ће бити развијени у целе сезоне серије; види саопштење за медије, Amazon Greenlights Full Seasons of Mad Dogs, The Man in the High Castle, The New Yorker Presents, and Children's Shows Just Add Magic and The Stinky \& Dirty Show, 18 February 2015, 8 March 2016, http://www.businesswire.com/news/home/20150218005667/en/Amazon-Greenlights-Full-Seasons-Mad-Dogs-Man

40 Walker, D. Amazon Renews Record-Streaming 'The Man in The High Castle' For Season Two, 21 December 2015, 1 March 2016, http://www.forbes. $\mathrm{com} /$ sites/davewalker/2015/12/21/amazon-renews-record-streaming-theman-in-the-high-castle-for-season-two/\#2881674262f8

41 Dick, P. K. How to Build a Universe That Doesn't Fall Apart Two Days Later, in: The Shifting Realities of Philip K. Dick: Selected Literary and Philosophical Writings, ed. Sutin, L. (1995), New York: Vintage/Random House, p. 278. 


\section{МЛАДЕН ЈАКОВЉЕВИЋ}

\section{ЛИТЕРАТУРА:}

Albahari, D. ur. (2005) Ji đing, deset krila: knjiga promene, Sremska Mitrovica: Tabernakl.

Bazin, A. Adaptation, or the Cinema Digest, in: Film and Literature: An Introduction and Reader, ed. Corrigan, T. (2012), New York: Routledge, pp. 57-64.

Bertrand, F. Philip K. Dick on Philosophy: A Brief Interview, in: The Shifting Realities of Philip K. Dick: Selected Literary and Philosophical Writings, ed. Sutin, L. (1995), New York: Vintage/Random House, pp. 44-47.

Corrigan, T. ed. (2012) Film and Literature: An Introduction and Reader, New York: Routledge.

Dick, P. K. How to Build a Universe That Doesn't Fall Apart Two Days Later, in: The Shifting Realities of Philip K. Dick: Selected Literary and Philosophical Writings, ed. Sutin, L. (1995), New York: Vintage/Random House, pp. 259-280.

Dick, P. K. Schizophrenia \& The Book of Changes, in: The Shifting Realities of Philip K. Dick: Selected Literary and Philosophical Writings, ed. Sutin, L. (1995), New York: Vintage/Random House, pp. 175-182.

Dick, P. K. Universe Makers... and Breakers, in: The Shifting Realities of Philip K. Dick: Selected Literary and Philosophical Writings, ed. Sutin, L. (1995), New York: Vintage/Random House, pp. 103-105.

Dik, F. K. (2008) Čovek u visokom dvorcu (prev. Rajković, M.), Beograd: Alnari.

Huang, A. (2009) Sveobuhvatni Ji Đing / definitivni prevod taoističkog majstora Alfreda Huanga, Beograd: Babun.

Jakovljević, M. (2015) Alternativne stvarnosti Filipa K. Dika, Kosovska Mitrovica/Beograd: Filozofski fakultet Kosovska Mitrovica/ Makart d.o.o.

Leitch, T. Twelve Fallacies in Contemporary Adaptation Theory in: Film and Literature: An Introduction and Reader, ed. Corrigan, T. (2012), New York: Routledge, pp. 104-122.

Stam, R. Beyond Fidelity: The Dialogics of Adaptation, in: Film and Literature: An Introduction and Reader, ed. Corrigan, T. (2012), New York: Routledge, pp. 74-88.

Sutin, L. ed. (1995) The Shifting Realities of Philip K. Dick: Selected Literary and Philosophical Writings, New York: Vintage/Random House.

Sutin. L. (2005) Divine Invasions: A Life of Philip K. Dick, New York: Carol \& Graf-Avalon.

Vest, J. P. (2007) Future Imperfect: Philip K. Dick at the Movies, Westport CT: Praeger Pubishers. 


\title{
МЛАДЕН ЈАКОВЉЕВИЋ
}

Vest, J. P. (2009) The Postmodern Humanism of Philip K. Dick, Lanham, Toronto, Plymouth: The Scarecrow Press, Inc.

Amazon Greenlights Full Seasons of Mad Dogs, The Man in the High Castle, The New Yorker Presents, and Children's Shows Just Add Magic and The Stinky \& Dirty Show, 18 February 2015, 8 March 2016, http://www.businesswire.com/news/home/20150218005667/en/Amazon-Greenlights-Full-Seasons-Mad-Dogs-Man

Walker, D. Amazon Renews Record-Streaming 'The Man in The High Castle' For Season Two, 21 December 2015, 1 March 2016, http:// www.forbes.com/sites/davewalker/2015/12/21/amazon-renews-recordstreaming-the-man-in-the-high-castle-for-season-two/\#2881674262f8

Walker, D. The Man in The High Castle Writer Frank Spotnitz on Adapting Philip K. Dick for Amazon, 18 November 2015, 1 March 2016, http://www.phoenixnewtimes.com/arts/the-man-in-the-highcastle-writer-frank-spotnitz-on-adapting-philip-k-dick-for-amazon-7830812

Mladen Jakovljević

University of Priština with temporary Head Office in Kosovska Mitrovica

\section{PHILIP K. DICK IN AMAZON'S CASTLE}

\begin{abstract}
Amazon's adaptation of The Man in the High Castle brings about numerous changes to the original Philip K. Dick's story. However, even if fidelity is no longer regarded as a valid criterion for evaluation of adaptation, as it is no longer considered essential in theory and criticism, the series is not an example of successful adaptation due to its failure to translate the key ideas of the novel into the new form. The series brings into focus elements that introduce, intensify and multiply Dick's fake fake instead of highlighting those that contribute to the discovery of inner truth. In its centering on the surface, visible consequences of the lost war and not on America as an authoritarian creation in which, due to endless replication, it is no longer possible to discern authentic objects, people and realities from the fake ones, the adaptation fails to highlight key social, economic and political problems and dilemmas that equally plague the present and the past, as Dick's unique fictional realities do. Unfortunately, the idea of fake fake is successfully conveyed to the viewers - or perhaps it would be more suitable to call them consumers - primarily by transforming the novel into a product with potential for commercial exploitation and its own replication into new seasons.
\end{abstract}

Key words: adaptation, science fiction, fictional realities, authentic, fake 